\title{
Ortaokul 8.Sınıf Türkçe Ders Kitaplarındaki Şiirlerde Yer Alan Değerler
}

\section{Erhan ÇAPOĞLU*}

Alpaslan OKUR ${ }^{* *}$

Öz

Bu araştırmanın amacı ortaokul bünyesinde okutulan 2012-2013 yılı 8.sınıf Türkçe ders kitaplarındaki şiir metinlerinin hangi değerlere sahip olduğunu ortaya koymaktır. Bu doğrultuda ortaokullarda okutulan 7 adet Türkçe ders kitabında (Koza, Özgün, Pasifik, TAV(Ada), Harf, Bisiklet, Enderun) bulunan toplam 33 adet şiir incelenmiştir. İnceleme 29 adet değerden oluşan değer inceleme formuyla yapılmıştır. İnceleme neticesinde şiirlerde 18 adet değer başlığı bulunmuştur. En fazla vurgu yapılan değerler insan sevgisi, doğa sevgisi ve Türk büyüklerine saygı değerleridir. İçinde en fazla değer bulunduran yayınevi Enderun yayınevidir. Ders kitaplarındaki şiirlerin bazılarının değer noktasında eksik ve işlevden yoksun olduğu görülmüş ve buna yönelik önerilerde bulunulmuştur.

Anahtar Kelimeler: Değer, şiir, Türkçe öğretimi.

\section{Poetry in Turkish Textbooks Found in Middle School 8th Grade Values}

\begin{abstract}
The aim of this study is taught within the 2012-2013 year 8th grade middle school textbooks in Turkish poetry texts reveal that which is worth having. In this direction, which is taught in secondary schools in Turkish textbooks 7 (Koza, Original, Pacific, TAV (Ada), letters, Cycling, Enderun) were examined a total of 33 pieces of poetry. Review the value of 29 units of values is made by examination form. Review title match has been found in verses 18 value. The maximum emphasis on the value of human love, great love of nature and respect for Turkish values. Enderun contain the maximum value of the publishing house is publishing. Some of the poems in textbooks, the value of the function at the point of missing and was found to be lacking and suggestions have been made for it.
\end{abstract}

Keywords: Value, poetry, Turkish education.

* Sakarya Üniversitesi Türkçe Eğitimi Bölümü Doktora Öğrencisi, capoglu.erhan@hotmail.com

** Doç. Dr., Sakarya Üniversitesi, Türkçe Eğitimi Bölümü, aokur@sakarya.edu.tr 


\section{GİRIŞ}

Yıllardan beri dünyada baş döndürücü bir değişim görülmektedir. $\mathrm{Bu}$ değişim sadece teknoloji alanında değil birçok alanda da kendisini göstermektedir. Bu hızlı değişime ayak uydurmaya çalışan insanoğlu bu değişimle birlikte birçok yeniliği, kolaylığ 1 ve rahatlığ 1 elde etmiştir. Elde edilen bu güzel şeylerin yanı sıra insanlar birçok şeyden de mahrum olmaya başlamıştır. Bu mahrumiyet neticesinde dünya içerisinde artan olumsuz olaylar her gün insanlığın gözleri önüne serilmektedir. İnsanlığın feragat ettiği bu kavramların başında dĕ̆er kavramı gelmektedir.

Değerler kullanıldığı anlam itibariyle birçok bilim alanının konusu olma özelliği taşımaktadır. Son yıllarda da eğitim alanında sıkça kullanılan bir kavram olmuştur (Kolaç-Karadağ, 2012: 763). Bu durum eğitim ile değerlerin eşgüdüm içerisinde ilerlemesini gerektirmiştir.

Değerlerin birçok bilim alanıyla ilgili olması ve değerler hakkında farklı bilim dalları içerisinde de çalışmaların yapılması değerlerin müstakil bir tanımının yapılmasını oldukça zorlaştırmıştır. Değer kavramı hakkında günümüze kadar pek çok bilimsel ve felsefi tartışmalar ve araştırmalar yapılmasına rağmen değerlerin tam olarak neler içerdiği konusunda tam bir fikir birliği sağlanamamıştır. Değer kavramının birçok bilim ile harmanlanmış olması da bu tartışmalar doğrultusunda değerlerin tanımını ve içeriğini belirlemeyi oldukça zor hale getirmiştir. (Ulusoy ve Dilmaç, 2012: 14).

Sosyal bilimlerde değer kavramını ilk kez Polonyalı bir sosyolog olan Florian Znaniecki kullanmıştır ve kavram Latince "kıymetli olmak" veya "güçlü olmak" anlamlarını içinde barındıran "valere" kökünden türetilmiştir (Bilgin, 1995: 83). Değer bir şeyin arzu edilebilir veya edilemez olduğu hakkındaki inançtır. Dolayısıyla değerlerin yapılan ve öğrenilen hareket ve eylemlerin niteliğine de vurgu yaptığ 1 görülmektedir (Güngör, 2000: 279). İnsanlar nasıl soğuk bir yer için kalın elbiseler giyinip soğuktan korunuyorsa nasıl İlkçağ'da olduğu gibi vahşi hayvanların saldırısından korunmak için mağaralara sığınıyorsa değerler de insanları kuşatan ve manevi olarak bünyesinde barındırıp koruyan araçlardır. Değer, insanı değerli kılan, sahip olduğu üstün nitelikler ve donanimlara verilen addir. (Yaman, 2012: 18).

$\mathrm{Bu}$ tanımlardan hareketle değerler bir toplumu oluşturan insanların istedikleri ve istemedikleri davranışlar için uydukları toplumsal normlar olarak tanımlanabilir. Bu uyulan toplumsal normlar, insanları toplum içerisinde kabul edilebilir kılar. Çünkü değerler toplumun bütünlüğünü ve devamlılığını kuşaklar vasıtasıyla sağlayan vasıtalardır (Ülken, 1986: 39). Örneğin; yıllar önce bir toplum büyük bir sıkıntı yaşamışsa ve insanlar bu sıkıntıyı el birliği ile aşmışsa bu kuşaktan kuşağa gelecek nesillere aktarılır. Yıllar sonra gene böyle bir sıkıntıda toplumun üzerinde düşen, yıllar önceki insanların ne yaptığını bilmiş olmaktır. Değerler bir toplum için o topluma ait ortak davranış kalıplarını temsil eder. Değerler toplum için yol gösterici bir pusula veya harita olarak da kabul edilebilir. Bu davranış kalıplarının bireye aktarılması, bireyin içinde bulunduğu toplumun bir parçası haline gelmesini sağlar (Kolaç-Karadağ, 2012: 764).

Literatürde değerlerle sıkça karşılaşılmaktadır. Böyle bir durum değerlerin oldukça geniş bir alana yayıldığını göstermektedir. Bundan dolayı değerler hakkında bir takım sınıflamaların yapılması gerekliliği ortaya çıkmıştır. Yapılan değer sınıflamalarından en fazla kabul edilenleri şunlardir: Spranger, Allport-VernonLidzey, Rokeach, Schwartz. Türkiye'de ise Takiyettin Mengüşoğlu, Erol Güngör değer sınıflandırmaları yapmıştır.

Psikoloji alanında değer testini ilk kez 1929 yılında Eduard Spranger yapmıştır. Spranger değerleri altı gruba ayırmış olup bunları: estetik, teorik, ekonomik, siyasi, sosyal ve dini değer grupları olarak açıklamıştır ve bu değer grupları daha sonra Gordon Allport,, Philip Vernon ve Gardner Lindzey tarafından bir ölçeğe dönüştürülmüştür (Akbaş, 2004: 55). (Tablo 1) Milton Rokeach ise değerleri "gaye 
değerler" ve "vasıta değerler" olmak üzere ikiye ayırmıştır (Güngör, 2000: 85). Bu iki ana gruptan oluşan siniflandirmada toplam 36 tane değer bulunmaktadır (Akbaş, 2004: 57). (Tablo 2). Schwartz ise Rokeach'nın değer sınıflaması üzerinde çalışarak 10 temel değer tipi gruplamiş ve toplam 56 tane değer belirtmiştir. (Tablo 3) (Kuşdil-Kağıtçıbaşı, 2000: 60-61).

Takiyettin Mengüşoğlu "İnsan Felsefesi" adlı kitabında değerleri 3 ana başlıkta toplamıştır. $\mathrm{Bu}$ başlıklar yüksek değerler, araç değerler,

Tablo 1. Allport-Vernon-Lindzey Değer Sınıflandırması

\begin{tabular}{ll}
\hline Bilimsel Değer & Gerçeğe, bilgiye, muhakemeye ve eleştirel \\
& düşünceye önem verir. Bilimsel değerleri olan \\
& insanlar deneysel, eleştirici, akılcı ve entelek- \\
& tüeldir. \\
Ekorarlı ve pratik olana önem verir. Ekonomik & değerlerim hayatta önemsenmesi gerektiğini belir- \\
& tir. \\
Estetik Değer & Simetri, uyum ve forma önem verir. Birey hayatı \\
& olayların bir çeşitliliği olarak görür. Sanatın top- \\
& lum için zorunluluk olduğunu düşünür. \\
Sosyal Değer & Başkalarını sevme, yardım ve bencil olmama \\
& esastır. En yüksek değer insan sevgisidir. Bu insan \\
& sevgisini insanlara sunar. Nazik ve sempatiktir. \\
Bencil değildir. & Her şeyin üstünde kişisel güç, etki ve şöhret \\
Politik Değer & vardır. Esas olan kuvvetle ilgilidir. \\
Dini Değeni bir bütün olarak kavrar ve kendisini onun & bütünlüğüne bağlar. Dini uğrunda dünyevi \\
& farzları feda eder. \\
\hline
\end{tabular}

davranış değerleridir (Akyol, 2010: 20). Yüksek değerler: Sevgi, bilgi, doğruluk, masumluk, saflık, dürüstlük, hak, adalet, güven, şeref, iyi vb. Araç değerler: Yarar, çıkar, kuşku, çekememezlik, kıskançlık ve her türlü maddesel değerler (para, mülkiyet vb.) Davranış değerleri: Görgü kuralları ve ulusların geleneklerinde bulunan değerler. Güngör (2010: 84)'e göre de değerler, estetik, teorik, iktisadi, siyasi, sosyal ve dinî değerler olarak sınıflandırılmıştır. farzları feda eder.

Tablo 2. Rokeach Değer Sinıflandırması

\begin{tabular}{ll}
\hline Gaye değerler & Vasita değerler \\
\hline Aile Güvenliği & Bağımsı Olma \\
Barış İçinde Bir Dünya & Bağışlayıcılık \\
Başarılı Olma & Cesaret \\
Bilgelik & Dürüstlük \\
Dini Olgunluk & Entelektüellik \\
Eşitlik & Geniş Görüşlülük \\
Gerçekler Dünyası & Hirslılık \\
Güzellikler Dünyası & İtaatkarlık \\
Heyecan verici bir Yaşam & Kendini Kontrol \\
İç Huzur & Kibarlık \\
Kendine Saygı & Kendine Hakim Olma \\
Mutluluk & Mantıklılık \\
Gerçek Dostluk & Neşelilik \\
Özgürlük & Sevecenlik \\
Rahat Bir Yaşam & Sorumluluk Sahibi Olma \\
\hline
\end{tabular}




\begin{tabular}{ll}
\hline Sosyal Kabul & Temizlik \\
Ulusal Güvenlik & Yardımseverlik \\
Zevk & Yaratıcılık \\
\hline
\end{tabular}

Tablo 3. Schwartz Değer Sınıflandırması

\begin{tabular}{ll}
\hline Değer Grupları & Değerler \\
\hline $\begin{array}{l}\text { Güç(power):Toplumsal konum, insanlar ve kay- } \\
\text { naklar üzerine denetim gücü }\end{array}$ & $\begin{array}{l}\text { Sosyal güç sahibi olmak, otorite sahibi olmak, } \\
\text { zengin olmak, toplumdaki görüntümü koruya- } \\
\text { bilmek, insanlar tarafından benimsenmek }\end{array}$
\end{tabular}

Başarı (achievement): Toplumsal standartları temel alan kişisel başarı yönelimi

Hazcılık (hedonism):Bireysel zevke, hazza yönelim

Uyarılım (stimulation):Heyecan ve yenilik arayışı

Özyönelim (self-direction):Düşünce ve eylemde bağımsızlık

Evrenselcilik (universalizm): Anlayışlılık, hoşgörü ve tüm insanların ve doğanın iyiliğini gözetmek

İyilikseverlik (benevolence):Kişinin yakın olduğu kişilerin iyiliğini gözetme ve geliştirme

Geleneksellik (tradition):Kültürel ya da dinsel töre ve fikirlere saygı ve bağlılık

Uyma (conformity): Başkalarına zarar verebilecek ve toplumsal beklentilere aykırı olabilecek dürtü ve eylemlerin sinıflandirılması

Güvenlik (security):Toplumun, var olan ilişkilerin ve kişinin kendisinin huzuru ve sürekliliği
Başarılı olmak, yetkin olmak, hırslı olmak, sözü geçen biri olmak, zeki olmak

Zevk, hayattan tat almak

Cesur olmak, değişken bir hayat yaşamak, heyecanlı bir yaşantı sahibi olmak

Yaratıcı olmak, merak duyabilmek, özgür olmak, kendi amaçlarını seçebilmek, bağımsız olmak,(kendine saygısı olmak

Açık fikirli olmak, erdemli olmak, toplumsal adalet, eşitlik, dünyada barış istemek, güzelliklerle dolu bir dünya, doğayla bütünlük içinde olmak, çevreyi koruma, iç uyum

Yardımsever olmak, dürüst olmak, bağışlayıcı olmak, sadık olmak, sorumluluk sahibi olmak, (gerçek arkadaşlık, olgun sevgi, manevi bir hayat, anlamlı bir hayat,

Alçakgönüllülük, dindar olmak, hayatın verdiklerini kabullenmek, geleneklere saygilı olmak, 1lımlı olmak, dünyevi işlerden uzaklaşmak

Kibarlık, itaatkar olmak, anne-babaya ve yaşlılara değer vermek, kendini denetleyebilmek

Ulusal güvenlik, toplumsal düzenin sürmesini istemek, temiz olmak, aile güvenliği, iyiliğe karşılık vermek, bağlılık duygusu ve sağlıklı olmak
Dilmaç (1999: 16) insanların hayatları için çok önemli gördükleri en belirgin 12 tane değer belirlemiştir. Bunlar; insanları sevme, uyumlu olma, hırsları kontrol altına alma, başkalarının mutluluğunu isteme, kendini kontrol etme, iyi insan olma, manevi değerlere inanma, yardım- sever olma, tecrübeli ve bilgili olma, dost edinme, evlat yetiştirme, eser oluşturma.

Winter \& Newton ve Kiripatrik (1998'ten aktaran, Ulusoy ve Dilmaç, 2012) 'e göre değerler üç kısımda incelenir. Bu ayrım insan topluluğuna göre yapılır. Bu değerler; ailevi değerler, toplumsal değerler ve bireysel değerlerdir. 
Avustralyalı doktor Andrew Refshauge değertir. Refshauge'ye göre temel değerler şunlardır: ler ayrıştırmasında temel değerlere yer vermiş-

Tablo 4. Refshauge Temel Değerler Sınıflandırması

$\begin{array}{ll}\text { Dürüstlük } & \text { Tutarlı bir şekilde güvenilir ve dürüst olma } \\ \text { Mükemmellik } & \begin{array}{l}\text { Hayatın her alanında maksimum başarı için } \\ \text { mücadele etme }\end{array} \\ \text { Saygı } & \begin{array}{l}\text { Kendine ve başkalarına saygılı olma farklı fikirlere } \\ \text { hoşgörülü davranma }\end{array} \\ \text { Sorumluluk } & \text { Kendine, çevreye ve topluma karşı sorumlu olma } \\ \text { Kalıtım } & \begin{array}{l}\text { Toplumun ve milletin sosyal ve ekonomik re- } \\ \text { fahindan minnettarlık duyma ve buna katkıda } \\ \text { bulunmak için aktif rol üstlenme }\end{array} \\ \text { İ̧birliği } & \begin{array}{l}\text { Uyumsuz olmama ve ortak başarı için barışçıl } \\ \text { yollarla işbirliği içerisinde bulunma }\end{array} \\ \text { Önemseme } & \text { Empati göstererek ve merhametli davranarak } \\ \text { kendini ve diğgerlerinin refahını düşüme }\end{array}$

İnsanın sosyal bir varlık olması mensubu olduğu toplumun içinde yaşamasından kaynaklanır. Yolunu kaybetmiş bir misafir için bir harita, denizde rotasını kaybetmiş bir kaptan için bir pusula ne kadar önemliyse bir insan için de değerler, toplumla bütünleşmesi için önemlidir. İnsanlar değerler vasıtasıyla toplumla uyum içerisinde yaşar ve değerlerden dolayı toplum ile bütünleşirler. İnsanın bünyesinde barındırdığı değerler, gelecekte kişiliğini, bakış açısını, davranışlarını hatta hayatını belirleyeceğinden, insanın belli başlı değerlerin farkına varması, gerekli değerleri kazanması, yeni değerler benimsemesi ve bunları kişiliğinin içerisinde eriterek davranışa dönüştürmesi gerekmektedir. Hemen hemen yaşam boyu devam eden bu değer kazanma, değer kazandırma süreçlerine değerler eğitimi denmektedir (Yaman, 2012:18).

Son yıllarda oldukça popüler olan değerler eğitimi her ne kadar yeni bir kavram olarak görünse de geçmişte ahlak eğitimi ve karakter eğitimi gibi adlar almış ve bu adlar altında verilen eğitimin güncel şartlara uyarlanmış şeklidir (Sancak, 2011: 16).

Değerler eğitiminde karşılaşılan durumlardan biri de değerler eğitiminin hangi yaş aralıklarında verilmesi gerektiğidir. Bu durum hakkında bilim çevrelerinde belirgin bir ittifak yoktur. Bazı bilim adamları değerler eğitiminin belirli yaş aralıklarında verilmesi gerektiğini belirtirler. Bunun sebebi belirli bir yaştan sonra bireyin zihinsel gelişiminde soyut düşünme becerisini kazanmasıdır. Ama değerler eğitimi 
her yaş aralığında verilebilir. Ama değerler eğitiminin her yaş grubuna verilmesi mümkündür. Kişilik gelişiminin \%80'inin ilk beş yaş evresinde tamamlandığı düşünüldügüunde özellikle ilk yılların öneminin daha da arttığı görülmektedir. (Ulusoy ve Dilmaç, 2012:62). Bu yaşlara bakıldığında bireylerin okula gelmeden belirli bir birikime sahip oldukları söylenebilir. Bu durum değerler eğitiminde ailenin ne denli önemli bir role sahip olduğunu gözler önüne sermektedir.

Değerler eğitiminin özellikle çocuklar üzerinde çok büyük bir etkisi vardır. Her ne kadar değerler eğitimi yaşam boyu bir süreç olarak kabul edilse de değerlerin kazandırılmasında çocukların özellikle okul öncesi dönemleri oldukça önemlidir. Bu dönemlerde çocuklar daha okula gitmedikleri için ailelerinin kontrolü altındadırlar. $\mathrm{Bu}$ durum ailelerin değerleri kazandırmada öncü rol oynadığını göstermektedir. Okul çağına gelen çocuklar için artık ikinci bir aile okuldur. Okulun bu dönemdeki çocuklar için bu denli önemli olduğunu düşünürsek okul çağında değerlerin kazandırılması için uygun teknik ve stratejilerinin geliştirilmesi gerekmektedir. Akbaş (2008: 9)' a göre okulların görevlerinden biri, okul programlarında açık olarak belirtilen veya belirtilmeyen değerleri öğretmek, öğrencileri belirlenen kurallar doğrultusunda disipline etmek, onların ahlaki gelişimine katkıda bulunmak ve karakterini olumlu yönde etkilemektir. Türkçe eğitiminin temel amacı ferdin sosyalleşmesini; içinde yaşadığı topluma, aileye sağlıklı uyumunu sağlamaktır Bu amacıyla birlikte Türkçe öğretiminin değerler eğitimiyle ne denli temas halinde olduğu görülmektedir. Anadili öğretimi eğitimin en önemli ve en hassas basamağı olup bu eğitimi iyi alan bireyler bu derste edindikleri bilgi ve birikimleri diğer derslere de aktarabilirler. Çünkü öğretim sadece dil ya da dilbilgisi öğretimi değil millete ait değerlerin öğretilmesi işidir. Her ne kadar değerlerin eğitimi açısından bütün derslerin sorumluluğu varsa da Türkçe dersinin bu sorumluluğu diğer derslere göre daha fazladır. Değerlerin nesilden nesile aktarılmasında edebi eserlerin önemli rolleri vardır. Edebi eserlerin sıklıkla kullanıldığı Türkçe dersleri, öğrencilere değer öğretiminde de önemli bir işlev üstlenmektedir (Özbay-Tayşi, 2011: 24) (YamanTaflan v.d., 2009: 110).

\section{YÖNTEM VE VERILLERIN ANALIZİ}

Bu çalışmada nitel araştırma yöntemlerinden biri olan betimsel tarama modeli kullanılmıştır.

"Tarama modelleri, geçmişte ya da hâlâ var olan bir durumu var olduğu şekilde betimlemeyi amaçlayan araştırma yaklaşımıdır. Araştırmaya konu olan, birey ya da nesne kendi koşulları içinde ve olduğu gibi tanımlanmaya çalışılır. Onları herhangi bir şekilde değiştirme, etkileme çabası gösterilmez. Bilinmek istenen şey vardır ve ordadır. Önemli olan onu uygun bir biçimde gözleyip belirleyebilmektir."( Karasar, 2006: 77)

Çalışmada 8.sınıf ders kitaplarında yer alan şiirler uzmanlar tarafından "Değer İnceleme Formu" na (DİF) göre incelenerek şiirlerin hangi değerleri içerdiği tespit edilmeye çalışılmıştır. Değer inceleme formu oluşturulurken, Güngör'ün (1993) değer sinıflandırmasından, Rokeach'ın (1973) araç değerler ve amaç değerler tablosundan, Yaman-Taflan-Çolak'ın ( 2009) ders kitaplarındaki değerler formundan yararlanılmıştır. Değer inceleme formu için Cronbach Alfa iç tutarlık katsayısı 0.768 olarak tespit edilmiştir. Değer İnceleme Formu (DİF) içerisinde yer alan değer başlıkları şunlardır: Misafirperverlik, yardımseverlik, hoşgörülü olma, toplumsal kurallara uyma, görgü kurallarına uyma, kültürel bilinç, aile bilinci, dini bilinç, ahlaki bilinç, dürüstlük, doğruluk, cesaret, duyarlılık, çalışkanlık, insan sevgisi, doğa sevgisi, hayvan sevgisi, büyüklere saygı, Türk büyüklerine saygı, milli bilinç, dil bilinci, yurt- 
taşlık bilinci, demokrasi hak ve özgürlükler, akılcılık, tutumlu olma, barış. Geçerlik çalışmalarında formda yer alan maddeler öğretmenler tarafından incelenmiştir. Değer inceleme formunda incelenen şiirlerde hangi değerler bulunmuşsa o değer formda işaretlenmiştir. Her uzmanın ortak belirtmiş olduğu değerler görüş birliği, bütün uzmanların ortak olarak belirtmediği değerler ise görüş ayrılığı olarak kabul edilmiştir. 103 tane değer uzmanlar tarafından ortak olarak belirtildiği için görüş birliği olarak , 11 tane değer ise uzmanlar tarafından ortak olarak belirtilmediği için görüş ayrılığı olarak kabul edilmiştir. Miles ve Huberman (1994)'ın belirttiği görüş birliği/görüş birliği+görüş ayrı- lığ1 formülüne göre uzlaşma yüzdesi 0.90 olarak bulunmuştur. Karasar (2011:165)'e göre bulunan değerin 0.75 ten küçük olması güvenirlik açısından sıkıntı doğurmaktadır. Her biri öğretmen olan uzmanlar aracılığılyla 8.sınıf Türkçe ders kitaplarında yer alan şiirlerden elde edilen verilerin yüzde ve frekans analizleri yapılmıştır.

\section{BULGULAR VE YORUM}

İncelenen 7 adet ders kitabındaki değerler her bir yayınevi için ayrı olarak düzenlenip tablolaştırılmıştır. Ayrıca her tablonun altında o yayınevinden incelen şiirler belirtilmiştir.

Tablo 5. Koza Yayınlarının Türkçe Ders Kitabında Bulunan Değerler

\begin{tabular}{lll}
\hline Koza Yayıncılık & $f$ & $\%$ \\
\hline İnsan Sevgisi & 3 & $17,65 \%$ \\
Doğa Sevgisi & 3 & $17,65 \%$ \\
Türk Büyüklerine Saygı & 2 & $11,76 \%$ \\
Duyarlılık & 1 & $5,88 \%$ \\
Yurttaşlık Bilinci & 1 & $5,88 \%$ \\
Vatanseverlik & 1 & $5,88 \%$ \\
Barış & 1 & $5,88 \%$ \\
Milli Bilinç & 1 & $5,88 \%$ \\
Çalışkanlık & 1 & $5,88 \%$ \\
Sorumluluk Alma & 1 & $5,88 \%$ \\
Akılcılık & 1 & $5,88 \%$ \\
Kültürel Bilinç & 1 & $5,88 \%$ \\
& 17 & \\
\hline
\end{tabular}

(İncelenen şiirler: 1-Atatürk Bir Çıkıştır İniş Değil, 2-Atatürk Kurtuluş Savaşı'nda, 3-Bu Sabah Hava Berrak, 4-Dönen Tekerlek, 5İnsanla Güzel, 6-Şehrin Üstünden Geçen Bulutlar, 7-Türküler Dolusu.)
Tablo 5 'te verilen bilgilere göre, 12 adet değer başlığı ve 17 tane değer bulunduğu tespit edilmiştir. "İnsan sevgisi ve doğa sevgisi" değerlerinin ön plana çıktığı görülmüştür. Değer başlığının fazla olması kitapta birçok değere yer verilmiş olmasını beraberinde getirmiştir. 
Tablo 6.Özgün Yayınlarının Türkçe Ders Kitabında Bulunan Değerler

\begin{tabular}{llc}
\hline Özgün Yayıncılık & $f$ & $\%$ \\
\hline Doğa Sevgisi & 3 & $27,27 \%$ \\
Türk Büyüklerine Saygı & 2 & $18,18 \%$ \\
İnsan Sevgisi & 1 & $9,09 \%$ \\
Hayvan Sevgisi & 1 & $9,09 \%$ \\
Çalışkanlık & 1 & $9,09 \%$ \\
Akılcılık & 1 & $9,09 \%$ \\
Milli Bilinç & 1 & $9,09 \%$ \\
Cesaret & 1 & $9,09 \%$ \\
\end{tabular}

(İncelenen şiirler: 1-Barışa Özlem, 2-Bursa'da Akşam, 3-Kara Toprak, 4-Kemal Atatürk, 5-O

Geliyor.)
Tablo 6'da verilen bilgilere göre, 8 adet değer başlı̆̆1 ve 10 tane değer bulunduğu görülmüştür. "Doğa Sevgisi ve Türk Büyüklerine Sayg1 " değerleri ön plana çıkmıştır

Tablo 7.Pasifik Yayınlarının Türkçe Ders Kitabında Bulunan Değerler

\begin{tabular}{lll}
\hline Pasifik Yayınları & $f$ & $\%$ \\
\hline Çalışkanlık & 2 & $16,66 \%$ \\
Kültürel Bilinç & 2 & $16,66 \%$ \\
Yardımseverlik & 1 & $8,33 \%$ \\
Türk Büyüklerine Saygı & 1 & $8,33 \%$ \\
Vatan Sevgisi & 1 & $8,33 \%$ \\
Akılcılık & 1 & $8,33 \%$ \\
Milli Bilinç & 1 & $8,33 \%$ \\
Dil Bilinci & 1 & $8,33 \%$ \\
Yurttaşlık Bilinci & 1 & $8,33 \%$ \\
Dürüstlük & 1 & $8,33 \%$ \\
\end{tabular}

(İncelenen şiirler: 1-Atatürk İlkeleri, 2-Cazgır, 3-Gidem Dersin Uçmağa, 4-Sazıma, 5-Seyfi Baba.)
Tablo 7'de verilen bilgilere göre, tespit edilen değer başlığı 10 tane olup değer sayısı 12 tanedir. "çalışkanlık ve kültürel bilinç" değerlerinin vurgulandığ́ görülmüştür.

Tablo 8. Tav-Ada Yayınlarının Türkçe Ders Kitabında Bulunan Değerler

\begin{tabular}{llc}
\hline Tav-Ada Yayıncılık & $f$ & $\%$ \\
\hline İnsan Sevgisi & 3 & $17,65 \%$ \\
Türk Büyüklerine Sayg1 & 3 & $17,65 \%$ \\
Doğa Sevgisi & 2 & $11,76 \%$ \\
Milli Bilinç & 2 & $11,76 \%$ \\
Kültürel Bilinç & 2 & $11,76 \%$ \\
Vatan Sevgisi & 2 & $11,76 \%$ \\
\hline
\end{tabular}




\begin{tabular}{lll}
\hline Dil Bilinci & 1 & $5,88 \%$ \\
Hoşgörülü Olma & 1 & $5,88 \%$ \\
Barış & 1 & $5,88 \%$ \\
& 17 & \\
\hline
\end{tabular}

(İncelenen şiirler: 1-Atatürk Kurtuluş Savaşı'nda, 2-Birlikte, 3-Çocuk Kitap, 4-Ellinci Y1l Türküsü, 5-Nutuk, 6-Türkçe Katında Yaşamak, 7-Türküler Dolusu, 8-Yedigöller'de Sonbahar.)

Tablo 8'de verilen bilgilere göre, 9 adet değer başlı̆̆1 ve toplam 17 tane değer tespit edilmiş-

Tablo 9. Harf Yayınlarının Türkçe Ders Kitabında Bulunan Değerler

\begin{tabular}{llc}
\hline Harf Yayıncılık & $f$ & $\%$ \\
\hline Çalışkanlık & 2 & $16,66 \%$ \\
Barış & 2 & $16,66 \%$ \\
Akılcılık & 1 & $8,33 \%$ \\
Doğa Sevgisi & 1 & $8,33 \%$ \\
Kültürel Bilinç & 1 & $8,33 \%$ \\
Duyarlılık & 1 & $8,33 \%$ \\
Sorumluluk Alma & 1 & $8,33 \%$ \\
Türk Büyüklerine Saygı & 1 & $8,33 \%$ \\
Yardımseverlik & 1 & $8,33 \%$ \\
İnsan Sevgisi & 1 & $8,33 \%$ \\
\end{tabular}

(İncelenen şiirler: 1-Dost, 2-Eylül Sabahının Serinliği, 3-Kemal Atatürk, 4-Odalar ve Sofalar, 5-Sazıma, 6-Şakacı Şiir.)

Tablo 9'da verilen bilgilere göre, 10 adet değer başlığ1 ve toplamda 12 adet değer bulunmuş-

Tablo 10. Bisiklet Yayınlarının Türkçe Ders Kitabında Bulunan Değerler

\begin{tabular}{lll}
\hline Bisiklet Yayınları & $f$ & $\%$ \\
\hline İnsan Sevgisi & 4 & $26,66 \%$ \\
Barış & 2 & $13,33 \%$ \\
Sorumluluk Alma & 2 & $13,33 \%$ \\
Doğa Sevgisi & 2 & $13,33 \%$ \\
Milli Bilinç & 1 & $6,66 \%$ \\
Hoşgörülü Olma & 1 & $6,66 \%$ \\
Hayvan Sevgisi & 1 & $6,66 \%$ \\
Türk Büyüklerine Saygı & 1 & $6,66 \%$ \\
Çalışkanlık & 1 & $6,66 \%$ \\
\hline
\end{tabular}

tur. Bulunan değerler göz önüne alındığında "Çalışkanlık" ve "Barış" değerlerinin en fazla olduğu görülmektedir. 
(İncelenen şiirler: 1-Atatürk'ten Son Mektup, 2Birlikte, 3-Doğa Dedi Ki, 4-Müjde, 5-Pırpırlı Şiir.)

Tablo 10'da verilen bilgilere göre, 9 adet değer başlığı ve toplamda 15 adet değer bulunmuş- tur. "İnsan sevgisi" değerinin ön plana çıktığı görülmektedir. Bu değerden sonra "Barış" ve "Sorumluluk Alma" değerleri diğer değerlere göre daha fazla ön plana çıkmıştır

Tablo 11. Enderun Yayınlarının Türkçe Ders Kitabında Bulunan Değerler

\begin{tabular}{lll}
\hline Enderun Yayınları & $f$ & $\%$ \\
\hline İnsan Sevgisi & 4 & $20 \%$ \\
Kültürel Bilinç & 3 & $15 \%$ \\
Türk Büyüklerine Saygı & 3 & $15 \%$ \\
Doğa Sevgisi & 3 & $15 \%$ \\
Milli Bilinç & 2 & $10 \%$ \\
Vatanseverlik & 2 & $10 \%$ \\
Dil Bilinci & 1 & $5 \%$ \\
Hoşgörülü Olma & 1 & $5 \%$ \\
Barış & 1 & $5 \%$ \\
& 20 & \\
\hline
\end{tabular}

(İncelenen şiirler: 1-Atatürk Kurtuluş Savaşı'nda, 2-Birlikte, 3-Çocuk Kitap, 4-Ellinci Y1l Türküsü, 5-Kütüphane, 6-Nutuk, 7-Sevgi, 8Türkçe Katında Yaşamak, 9-Türküler Dolusu, 10-Yedigöllerde Sonbahar.)

Tablo 11'de görüldüğü gibi 9 adet değer başl1ğ1 ve toplam 20 tane değer bulunmuştur. En

Tablo 12. Bütün Kitaplarda Bulunan Değerler Toplamı

\begin{tabular}{lll}
\hline & $f$ & $\%$ \\
\hline İnsan Sevgisi & 16 & $15,38 \%$ \\
Doğa Sevgisi & 14 & $13,46 \%$ \\
Türk Büyüklerine Saygı & 13 & $12,5 \%$ \\
Kültürel Bilinç & 9 & $8,65 \%$ \\
Milli Bilinç & 8 & $7,69 \%$ \\
Çalışkanlık & 7 & $6,73 \%$ \\
Barış & 7 & $6,73 \%$ \\
Vatanseverlik & 6 & $5,76 \%$ \\
Sorumluluk & 4 & $3,84 \%$ \\
Akılcılık & 4 & $3,84 \%$ \\
Hoşgörülü Olma & 3 & $2,88 \%$ \\
Dil Bilinci & 3 & $2,88 \%$ \\
Yurttaşlık Bilinci & 2 & $1,92 \%$ \\
Duyarlılık & 2 & $1,92 \%$ \\
\hline
\end{tabular}

fazla yer verilen değer "İnsan sevgisi" olarak tespit edilmiştir. İnsan sevgisi değerinden sonra "Kültürel bilinç, Türk büyüklerine saygı ve doğa sevgisi" değerleri diğer değerlere göre ön plana çıkmıştır. 


\begin{tabular}{lll}
\hline Yardımseverlik & 2 & $1,92 \%$ \\
Hayvan Sevgisi & 2 & $1,92 \%$ \\
Doğruluk & 1 & $0,96 \%$ \\
Cesaret & 1 & $0,96 \%$ \\
\hline
\end{tabular}

İncelenen sınıf seviyesi 8.sınıftır. İncelenen kitaplarda toplam 104 adet değer bulunmuştur. Her kitap için bulunan değerler tabloda verilmiştir. Tablolardan göze çarpan değerler "İnsan sevgisi, Türk büyüklerine saygı ve doğa sevgisi" değerleridir. Özellikle insan sevgisi her ne kadar bazı kitaplarda en fazla bulunan değer olsa da bütün kitaplarda hemen hemen ortak olarak bulunmaktadır.

\section{SONUÇ VE ÖNERILLER}

Ülkemizde işlenen her ders değerlerin aktarımindan ve değerlerin eğitiminden sorumludur. Bu sorumluluk dairesinde Türkçe dersi oldukça önemli bir yere sahiptir. Türkçe dersi içerik olarak metin ve şiir gibi materyaller bulundurduğundan değerler eğitiminin yapılması için oldukça elverişli bir derstir. Ayrıca Türkçe dersinin ortaokul seviyesindeki ders saatleri 5 . ve 6 . siniflarda 6 saat, 7 . ve 8 . siniflarda 5 saattir. Bu ders saatlerine bakıldığında Türkçe dersi bu sınıf seviyelerinde en fazla ders saatine sahip bir derstir. Bu yüzden değerler eğitimi ile Türkçe dersi oldukça ilişkilidir.

Çalışmada ders kitapları hakkında bazı sonuçlara ulaşılmıştır. İncelenen ders kitaplarında en fazla değer, 12 değer başlığı ile Koza Yayınları'nda bulunmuştur. Değer başlığının fazla olması metinlerde değer çeşitliliğini göstermektedir ve değer aktarımı olarak da oldukça faydalı bir durumdur. En az değer başlı̆̆1 ise 8 adet değer başlı̆̆ı ile Özgün Yayınları'nda bulunmuştur. En fazla değer ise 20 tane ile Enderun Yayınları'nda bulunmuştur. Bu yayınevinin kitabında ise değer başlı̆̆ının 9 olup değer sayısının 20 olması seçilen metinlerin değer aktarımı açısından ideal metinler oldu- ğunu göstermektedir. İncelenen ders kitaplarına bakıldığında Koza ve Enderun Yayınları'nın ders kitaplarının diğer ders kitaplarından önde olduğu görülmektedir. Koza Yayınları'nın metinlerinde diğer yayınların metinlerine göre daha fazla değer başlığı bulunmaktadır. Bu durum bu kitabı kullanan öğrencilerin çok farklı değerlerle karşılaşacağını göstermektedir. Enderun Yayınları'nın metinlerinde ise diğer yayınların metinlerine göre daha fazla değer bulunmaktadır. Böylelikle bu ders kitabını kullanan öğrenciler değer konusunda oldukça zengin metinlerle karşılaşacak ve bir metinde birden fazla değeri öğrenmiş olacaklardır. Bütün ders kitapları değerlendirildiğinde toplam 18 adet değer başlığı ve 104 tane değer bulunmuştur. En fazla vurgulanan değerlerin "İnsan sevgisi", "Doğa sevgisi" ve "Türk büyüklerine sayg1" değerlerinin olduğu görülmüş en az vurgulanan değerlerin ise "Doğruluk" ve "Cesaret" değerlerinin olduğu görülmüştür.

Ders kitaplarında vurgulanan bazı değerlerin, çalışmanın başlarında verilmiş olan değer sınıflandırmalarıyla paralel olduğu görülmüştür. En fazla vurgulanan "İnsan sevgisi" değeri Allport-Vernon-Lindzey Sınıflandırması içerisinde Sosyal Değer'e karşılık gelmektedir. Çalışmada vurgulanan insan sevgisi, doğa sevgisi, barış, duyarlılık gibi değerler Schwartz'ın Sınıflandırması içerisinde Evrenselcilik (universalism) değer grubu içerisindeki değerlere; yardımseverlik, sorumluluk ve hoşgörülü olma ise İyilikseverlik (benevolence) değer grubu içerisindeki değerlere paraleldir. Ayrıca Türk büyüklerine saygı, kültürel bilinç ve milli bilinç değerleri de gene Schwartz'ın sınıflandırmasında Geleneksellik (tradition) 
değer grubu içerisindeki değerlerle paraleldir. Çalışmada bulunan "çalışkanlık", "sorumluluk", "hoşgörülü olma”, “doğruluk” değerleri ise Refshauge'nin temel değerleriyle paraleldir.

Türkçe derslerinde kullanılacak ders kitaplarında bulunan şiirlerdeki değerlerin biraz daha arttırılması değerlerin aktarımında daha işlevsel olmasını sağlayacaktır. Ders kitaplarında yer alan şiirlerin değer konusunda daha yoğun olması değer aktarımına oldukça fazla katkıda bulunabilir. Bu konuda ders kitaplarına alınacak şiirlerin seçimine de dikkat edilmesi gerekmektedir. Bu şiirlerin değer olarak yoğun olmasının yanı sıra şiirlerde işlenen değerler arasında da bir uyum olmalıdır. Bir değer vurgulanırken diğer değerler görmezden gelinmemelidir. İşlenen değerlerin öğrenci seviyesine uygun olması da önemlidir. Öğrenci seviyelerine göre değerler uzmanlarca tespit edilmelidir.

Çalışmada 8. Sınıf kitapları üzerinde durulmuştur. İlerleyen zamanlarda diğer sınıf düzeylerinde veya şiir türlerine yönelik çalışmalar ve MEB'in belirlediği 100 Temel Eser'de yer alan şiir metinlerindeki değerler üzerine çalışmalar yapilabilir.

\section{Kaynakça}

Akbaş, O. (2004). Türk milli ĕ̆itim sisteminin duyuşsal amaçlarının ilköğgretim ikinci kademesindeki gerçekleşme derecesinin değerlendirilmesi. Yayımlanmamış doktora tezi, Gazi Üniversitesi Eğitim Bilimleri Enstitüsü: Ankara.

Akbaş, O. (2008). Değer eğitimi akımlarına genel bir bakış. Değerler Ĕ̆gitimi Dergisi , 6 (16), 9-27.

Akyol, Ş. (2010). İlköğretim 6.sınıf türkçe ders kitaplarında yer alan sevgi temasının değerler eğitimi açısından incelenmesi. Yayımlanmamış yüksek lisans tezi, ÇOMÜ Sosyal Bilimler Enstitüsü: Çanakkale.

Bilgin, N. (1995). Sosyal psikolojide yöntem ve pratik çalışmalar. İstanbul: Sistem Yayıncılık.

Güngör, E. (2000). Değerler psikolojisi üzerine araştırmalar. İstanbul: Ötüken Yayınları.

Günyüz, M., Sümer, A., Kansu, S. ve Yavuz, Y. (2008). 8.sınıf türkçe ders kitabı. İstanbul: Harf Yayınları.

Günyüz, M., Yeşil, Y., Sümer, A., Yüksel, Y. ve Kansu, S. (2010). 8.sınıf türkçe ders kitabı. Ankara: Özgün Yayınları.

Kapulu, A. ve Karaca, A. (2010). 8.sınıf türkçe ders kitabı. Ankara: Koza Yayın Dağıtım.

Karasar, N. (2006). Bilimsel araştırma yöntemleri. Ankara: Nobel Yayın Dağıtım.

Kolaç, E. ve Karadağ, R. (2012). türkçe öğretmeni adaylarının "değer" kavramına yükledikleri anlamlar ve değer sıralamaları. İlköğretim Online, 11(3), 762-777.

Kurt, M., Altay, J. ve Kara, M. (2010). 8.sınıf türkçe ders kitabı. Ankara: TAV Yayınları.

Kuşdil, E. ve Kağıtçıbaşı, Ç. (2000). Türk öğretmenlerin değer yönelimleri ve schwartz değer kuramı. Türk Psikoloji Dergisi, 45, 59-76.

Mengüşoğlu, T. (1988). İnsan felsefesi. İstanbul: Remzi Kitabevi.

Özbay, M. ve Tayşi, E. K. (2011). Dede korkut hikâyeleri'nin türkçe öğretimi ve değer aktarımı açısından önemi. Pegem Ĕ̆itim ve Öğretim Dergisi, 1(1), 21-31.

Sancak, Y. (2011). Mevlana'nın Mesnevi Adlı Eserinin Sosyal Bilgilerde Değer Kazanımındaki Rolü. Yayımlanmamış yüksek lisans tezi, Niğde Üniversitesi Sosyal Bilimler Enstitüsü, Niğde.

Şahin, D. (2012). 8.Sınıf Türkçe Ders Kitabı. Ankara: Ada Matbaacılık. 
102 | SAÜ Eğitim Bilimleri Enstitüsü

Ulusoy, K. ve Dilmaç, B. (2011). Değerler Eğitimi. Ankara: Pegem Akademi Yayıncılık.

Yaman, E. (2012). Değerler Ĕ̆itimi: Eğitimde Yeni Ufuklar. Ankara: Akçă̆ Yayınları.

Yaman, H., Taflan, S. ve Çolak, S. (2009). İlköğretim İkinci Kademe Türkçe Ders Kitaplarında Yer Alan Değerler. Değerler Ĕ̆itimi Dergisi, 7(18), 107-120. 


\section{Extended Summary}

Todays, it has been seen that there is an enormous change. Tha fast progress of technology in many areas the changes clear. The changes provide various easinesses in the life of human. These various easinesses bring various negativities with itself. Especially, it appears negative situation that people constituting the society adopt the features that aren't in their own society or aren't suitable to their society. We see the value concept in this negative situation. Values are social rules formed by people and they are based on their desires. The function of the social rules obeyed by people is that people are included in the society. Because the values are vehicles that providing the integrity and progress of society. Values are necessary guides in order to understand and introduce the society. So the values of the society are the mirrors of society. The first person mentioning the value in sociology is Polish sociologist Forian Znaniecki and Word comes from the basic of "valere" including the meanings which are being strong and valuable. Taking olace of values in many science areas makes clear that it is necessary to make classification. Spranger, Allport-Verman, Lidzey are the most known about the value classification. İt is possible to claim social values and to transfer them with the education of values. The education of values which is benefical to society requires process. Children will come across the high school after the primary school when we looak at the lesson program of secondary school, we see that there are more lessons related to Turkish. It is clear that Turkkish lesson has an important affect on the transfer of values. Because it has lots of lessons and it is our native language. When it is thought that the basic aim of the Turkish education is to make person social, it is seen that Turkish teaching is connected with values education. Because people can transfer the knowledge to other areas. Although all of the lessons are responsible fort he values education, the responsibility of Turkish lesson is more than other. The aim of this study is to appear values in the poems used in 8. Class Turkish lesson boks. The method of study is descriptive survey model which is the one of qualitative research method. The form of searching values is formed in order to determine the values in the poems of lesson boks with the forming this form we benefit from classification of Güngör (1993) and table of Rokeach (1903). For the form of values research, 0.768 is determined as the efficient of Cronbach Alfa. The matters in the form are researched by the teacher. Thirty-three poems taking place in seven Turkish lesson boks (Koza, Özgün, Pasifik, Tav, Harf, Bisiklet, Enderun) have been researched. This resarch is made with the research of form with twentynine values.

This research has been done with Turkish teachers being good at their areas. The values being shared are accepted together. If there is a valued that one or two expert claims, that values is accepted as a divergence of opinion. The people evaluating asserted by Miles and Huberman (1994) increase the percent of agreement. It becames 0.90. According to Karasar (2011:165), if the percent is more smaller than 0.75 it can be a problem. In the book of Koza researched, seven poems are researched and twelve value topic and seventheen values are indicated. Human love and nature love become first. In Özgün boks five poems are researched and eight value topics and ten values are indicated. Nature love and respect to Turkish elders are first. In the Pasifik boks, five poems are researced, eleven value topics and twelve values are found. Success and cultural conciousness are pointed. In Tav-Ada publication, eight poems are researched, nine value topics and seventheen values are found. It gives importance to success and peace. In Bisiklet publication, five poems are researched, nine value topics and fiftheen values are found. The most important value is human love and than peace and responsibility. In Enderun publication, ten poems are researched, nine value topics and twenty values are found. The most important value is hu- 
man love after than cultural conciousness and nature love. At the end of study, in thirty-three poems under the eighteen value topics one hundred-four values are indicated. The most important values are human love, nature love and respect to Turkish elders. Turkish lesson is important to transfer the values with necessary materials. We can benefit so much from Turkish lesson in this field. Turkish lesson boks are important in the Turkish lesson. So the increase of values in lesson books' poems is important for transfering the values. If the poems in the lesson boks are so many, it provides many advantages to transfer values. So it should be taken into consideration to poems in lesson books. 